\author{
A congressional investigation alleges that some researchers have failed to report all the drug-company \\ money that they have received - and that universities may have been too slow to police them.
}

\rceil he case of Charles Nemeroff, who as chair of the psychiatry department at Emory University in Atlanta, Georgia, allegedly underreported his income from drug companies, offers some stark revelations. Not only does it seem that Nemeroff was able to skirt around rules for reporting income, but Emory's officials appeared unable to rein him in.

A string of internal Emory documents and e-mails made public last week after a hearing of the US Senate Committee on Finance, chaired by Senator Charles Grassley (Republican, Iowa), allege a web of consulting, lecturing and advisory-board relationships that Nemeroff maintained with 16 pharmaceutical companies. By obtaining figures from each of the companies and comparing them with Nemeroff's financial disclosure forms provided by Emory, the committee's investigators alleged that, in breach of university rules, he failed to report at least $\$ 1.2$ million in income that these relationships earned him between 2000 and 2006.

In fairness, Emory medical school's Conflict of Interest Committee conducted an in-house investigation of Nemeroff's consulting in 2004. The committee alleged that he had committed "serious" violations of rules on reporting financial interests. Nemeroff accordingly promised in writing to keep his consulting with drugmaker GlaxoSmithKline (GSK) to less than $\$ 10,000$ annually - the threshold beyond which, under National Institutes of Health (NIH) rules, institutions must actively manage or eliminate entirely their NIH-funded researchers' conflicts.

GSK was of special concern because, from 2003 to 2008, Nemeroff was principal investigator on a $\$ 4$-million NIH grant examining five GSK antidepressant candidates. Figures given to Grassley's investigators by GSK allege that, despite his written promise, Nemeroff's compensation from the company totalled $\$ 171,000, \$ 78,000$ and $\$ 33,000$ in 2004, 2005 and 2006, respectively. His disclosure forms to Emory in those same years allegedly showed payments of $\$ 9,999$ per year, or of no specified amount.

Asked by Nature last week why Nemeroff was not disciplined in 2004 when his violations first emerged, the university responded that its 2004 internal report documenting his breach of the rules "speaks for itself". It added that the public documents show that it has "worked diligently" with Nemeroff to manage his alleged conflicts of interest. The university also noted that it is planning a "thorough investigation" of the allegations made by Grassley and that it is emphasizing its disclosure policies to all staff members.

The 2004 report did indeed lay down the law to Nemeroff. Yet Emory officials did not audit his income to be sure that he had reformed. Nemeroff stepped down as psychiatry chair only earlier this month, on the eve of the first newspaper report detailing his actions. Of course, the university's financial interests are tied up in the case too. Some $\$ 1.35$ million of the NIH grant went to Emory for overhead costs. Nemeroff did not respond to Nature's requests for comment. However, in a statement issued by Emory, he said: "To the best of my knowledge, I have followed the appropriate University regulations concerning financial disclosures. ... I will cooperate fully and work with Emory to respond to the alleged conflicts of interest issues raised by Senator Grassley and his staff.'

It is tempting to dismiss this case as a 'one-bad-apple' situation. But Nemeroff is the seventh academic psychiatrist this year that Grassley has exposed as allegedly underreporting drug-company income. His office says that there are more revelations to come. Grassley has begun pressuring the NIH to mete out real punishment - as in, pulling grants - to spur institutions to enforce proper reporting. The agency came close last week, when it imposed conditions on Emory requiring written assurance that proper disclosures have been made for every grant before it will give funds to the university. Departing NIH director, Elias Zerhouni, has also launched a time-intensive administrative revamp of the rules governing conflict-of-interest reporting by universities. His successor should make it a priority to speed up this process.

Grassley, meanwhile, has proposed a Physician Payments Sunshine Act. Introduced in Congress last year, it would legally oblige drug and device companies to post in a publicly accessible database all payments of more than $\$ 500$ that they make to physicians. This would markedly ease the task of universities in enforcing proper reporting, and would exonerate the many researchers who play by the rules but who are nonetheless being cast under a cloud by Grassley's investigation. Congress ought to pass the bill into law when it next convenes.

\section{Cut-throat savings}

\section{In an attempt to boost its struggling economy, Italy's} government is focusing on easy, but unwise, targets.

\footnotetext{
$\mathrm{t}$ is a dark and angry time for scientists in Italy, faced as they are with a government acting out its own peculiar cost-cutting philosophy. Last week, tens of thousands of researchers took to the streets to register their opposition to a proposed bill designed to
}

control civil-service spending (see page 840). If passed, as expected, the bill would dispose of nearly 2,000 temporary research staff, who are the backbone of the country's grossly understaffed research institutions - and about half of whom had already been selected for permanent jobs.

Even as the scientists were marching, Silvio Berlusconi's centreright government, which took office in May, decreed that the budgets of both universities and research could be used as funds to shore up Italy's banks and credit institutes. This is not the first time that Berlusconi has targeted universities. In August, he signed a decree that cut 